\title{
Pengaruh waktu perkawinan pasca beranak terhadap performa produk- tivitas sapi induk pada kondisi peternakan rakyat
}

\section{The influence of post-partum mating time on the productivities perfor- mance of cows in smallholder farmers}

\author{
Lukman Affandhy*, D. M. Dikman dan D. Ratnawati \\ Loka Penelitian Sapi Potong \\ Jalan Pahlawan Grati 02 Kabupaten Pasuruan (67184) Jawa Timur, Indonesia
}

Submitted: 28 Februari 2019, Accepted: 16 Juli 2019

\begin{abstract}
ABSTRAK: Perkawinan sapi induk merupakan faktor penting dalam usaha perbibitan peternakan rakyat. Penelitian bertujuan untuk memperoleh waktu perkawinan sapi induk pasca beranak di kondisi peternakan rakyat. Penelitian dilakukan di Kabupaten Pasuruan dan Probolinggo Provinsi Jatim. Pengamatan dilakukan terhadap reproduksi dan produksi pada 280 sapi induk Peranakan Ongole (PO) selama tahun 2010-2013. Penelitian menggunakan rancangan acak kelompok dengan empat kelompok perlakuan waktu perkawinan sapi pasca beranak bebeda, yaitu Kelompok I ( $<60$ hari), Kelompok II (60-<90 hari), Kelompok III (90$<120$ hari), dan Kelompok IV (>120 hari); dengan jumlah masing-masing adalah 18, 57, 74 dan 59 ekor induk. Parameter: post partus anoestrus/PPAI, service per conception (S/C), conception rate (CR), waktu penyapihan pedet, dan calving interval/CI, persentase kelahiran dan kematian pedet. Data dianalisis menggunakan Anova; dilanjutkan dengan uji Duncan menggunakan SPSS. Nilai PPAI pada sapi induk PO menunjukkan perbedaan sangat nyata $(\mathrm{P}<0,01)$ antara kelompok waktu perkawinan; dengan PPAI pada

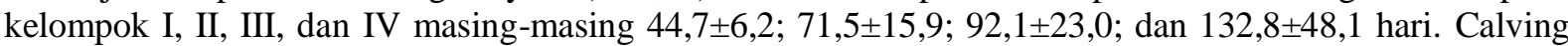
interval pada kelompok IV menunjukkan nilai tertinggi 499,0 123,4 hari $(\mathrm{P}<0,05)$ dibandingkan dengan dengan kelompok I, II, III. Nilai CR tertinggi dicapai pada kelompok III $(79,45 \%)$ daripada CR I, II dan IV. Mortalitas pedet tertinggi dicapai pada kelompok I (16,67\%) daripada kelompok II, III dan IV\%. Persentase kelahiran pedet pada kelompok I, II, III dan IV adalah sama; namun waktu penyapihan pedet terendah diperoleh pada kelompok perkawinan II 92,8 $\pm 22,5$ hari $(\mathrm{P}<0,01)$ daripada kelompok I, III dan IV. Disimpulkan bahwa waktu perkawinan sapi induk yang efisien adalah $60-<90$ hari pasca beranak.
\end{abstract}

Kata kunci: Induk PO; pasca beranak; perkawinan; performans reproduksi.

\begin{abstract}
The mating of the beef cow is important factors in beef cattle breeding. The research aims to obtain the mating time of the cow after calving in smallholder farmers. The study was conducted on Pasuruan and Probolinggo Regency, East Java Province. Observations were on productivities performance in Ongole-cross breed cows in smallholder farmers from 2010 to 2013. The study used a randomized block design with four treatment groups postpartum mating, namely Group I ( $<60$ days), Group II (60-<90 days), Group III (90-<120 days), and Group IV ( $>120$ days. The parameters measured included postpartum anoestrus interval/PPAI, service per conception (S/C), conception rate (CR), calf weaning time, and calving interval/CI, percentage of calf birth and death. Data were analyzed using ANOVA; followed by the Duncan test using SPSS. The values of PPAI in PO cows showed very significant differences $(\mathrm{P}<0.01)$ between the mating time groups. Calving Interval in group IV showed the highest value of $499.0 \pm 123.4$ days $(\mathrm{P}<0.05)$ compared with group I, II, III. The highest CR value was in group III (79.45\%) than I, II and IV. The highest calf mortality was in the group I (16.67\%) than in group II, III and IV. The percentage of calf births in groups I, II, III, and IV are the same, but the lowest calf weaning time of obtained in group II mating was $92.8 \pm 22.5(\mathrm{P}<0.01)$ than group I, III and IV. In conclusion, the most efficient mating time was $60-<90$ days after calving.
\end{abstract}

Keywords: Ongole-cross breed cows; post-partum; mating; reproductive performance.

"Corresponding Author: lukmansingosari@gmail.com

DOI: 10.21776/ub.jiip.2019.029.02.07 


\section{PENDAHULUAN}

Perkawinan sapi induk merupakan merupakan salah satu faktor penting dalam usaha perbibitan peternakan rakyat. Beberapa faktor lain yang berpengaruh diantaranya pakan, pemilihan bibit dan kesehatan ternak. Manajemen perkawinan sapi yang telah dilakukan oleh peternak, diantaranya inseminasi buatan (IB), kawin alami atau kombinasi antara IB dan kawin alami. Perkawinan sapi dengan IB biasanya dilakukan di kawasan Pulau Jawa, sebagian Sumatera, dan Sulawesi. Namun apabila perkawinan dengan IB gagal, peternak mengawinkan sapinya dengan pejantan alami. Waktu IB berkaitan erat terhadap angka kebuntingan sapi. Tingkat kebuntingan tertinggi didapatkan pada waktu IB dilakukan pada akhir estrus (Udin et al., 2016).

Permasalahan reproduksi pada sapi induk di kondisi peternakan rakyat diantaranya panjangnya masa kosong atau Days Open (DO). Penyebabnya adalah pedet tidak disapih sehingga induk tidak segera birahi. Kegagalan kebuntingan dan berulangnya IB menyebabkab angka S/C yang tinggi sehingga memperpanjang masa kosong (Susilawati dan Affandhy, 2004). Panjangnya DO menyebabkan panjangnya CI. Hal ini sesuai yang dilaporkan oleh Ihsan dan Wahyuningsih (2011), bahwa sapi Peranakan Limousin memiliki nilai CI-nya lebih tinggi (451,3 $\pm 19,61$ hari) dibandingkan dengan CI sapi PO (430 $\pm 43,72$ hari). Fauziah, Busono dan Ciaptadi (2015), menyatakan bahwa DO dan CI sapi Peranakan Ongole dan Peranakan Limousin pada paritas dua dan tiga masing-masing sebesar $117,8 \pm 16,5$ hari dan 397,6 $\pm 16,6$ hari. Suharyati dan Hartono (2016) menyatakan bahwa CI pada sapi Bali Kab. Pringsewu mencapai 416,69 $\pm 70,03$ hari. Manajemen pemeliharaan peternak dapat mempengaruhi CI ternak. Beberapa faktor yang mempengaruhi diantaranya: umur pertama kali dikawinkan, pemberian pakan, kondisi tubuh dan umur penyapihan pedet. Kondisitubu ternak menggambarkan status nutrisi ternak. Skor kondisi tubuh ternak harus dalam kondisi yang optimal saat menjelang atau sesudah beranak, untuk menjamin siklus reproduksi tetap berjalan optimal. Adanya keseimbangan energi yang negarif berpengaruh buruk terhadap reproduksi induk. Peningkatan intake energi selama 20-25 hari sebelum atau selama masa kawin serta dikombinasi dengan penyapihan atau pembatasan penyusuan dapat meningkatkan angka kebuntingan induk (Astessiano et al., 2011).

Angka kebuntingan ternak dipengaruhi oleh deteksi estrus, kualitas dan penanganan semen, kesuburan betina, teknik inseminasi, serta waktu perkawinan (Sudirman, 2016). Penelitian bertujuan ini untuk memperoleh waktu perkawinan sapi induk pasca beranak terhadap produksi dan reproduksinya pada kondisi peternakan rakyat di lahan kering di Jawa Timur.

\section{MATERI DAN METODE}

Penelitian dilakukan di lahan kering, yakni di Kec. Nguling Kab. Pasuruan dan Kec. Tongas Kab. Probolinggo Prov. Jawa Timur. Penelitian meliputi pengamatan reproduksi terhadap 208 ekor sapi induk Peranakan Ongole Ongole (PO) milik peternakan rakyat selama empat tahun (tahun 2010-2013), dengan melibatkan 100 petani peternak. Kunjungan ke peternak untuk pengamatan dilakukan secara reguler oleh petugas khusus (Junior Scientist) yang telah ditunjuk sekaligus sebagai kolekting data penelitian pada lokasi penelitian.

Pengamatan yang dilakukan meliputi data-data penimbangan bobot badan (BB), penilaian skor kondisi tubuh (SKT) secara visual pada skala 1-5 pada sapi induk dan pedetnya. Pengukuran BB dan SKT dilakukan setiap bulan selama pada tahun pertama kegiatan pelaksanaan penelitian berjalan dan setiap dua bulan sekali pada tahun berikutnya. Penimbangan $\mathrm{BB}$ ini digunakan untuk menghitung rata-rata pertambahan bobot harian harian $(\mathrm{PBBH})$ induk dan pedetnya. Pengamatan deteksi es- 
trus dilakukan secara visual meliputi tandatanda gelisah, keluarnya lendir bening, pembengkakan dan memerahnya vulva (Affandhy, Aryogi dan Tiesnamurti, 2014).. Pemberian pakan ternak dilakukan sesuai dengan BB ternak meliputi pemberian rumput gajah (Penesetum pupureum), legume (Glyrecidea maculata), jerami padi dan penambahan konsentrat komersial (saat dua bulan sebelum dan sesudah kelahiran). Perkawinan dilakukan dengan IB sesuai dengan tanda-tanda birahi yang telah diamati secara rutin. Penyapihan pedet dilakukan mulai umur 3-6 bulan dengan cara diikat atau dipisahkan dari induknya.

Pengambilan data sampling melibatkan petugas junior scientist dengan bertugas mencatat semua data setiap hari.

Data yang diperoleh dikelompokan menggunakan rancangan acak kelompok dengan empat kelompok perlakuan waktu perkawinan sapi pasca beranak berbeda yaitu:

a) Kelompok I (perkawinan $<60$ hari pasca beranak) dengan jumlah sapi induk 18 ekor,

b) Kelompok II (Perkawinan 60- <90 hari pasca beranak), dengan jumlah sapi induk 57 ekor,

c) Kelompok III (Perkawinan 90- <120 hari pasca beranak), dengan jumlah sapi induk 74 ekor,

d) Kelompok IV (Perkawinan $>120$ hari pasca beranak) dengan jumlah sapi minduk 59 ekor.
Data dianalisis menggunakan $\mathrm{Mi}$ crosoft excel dan SPSS (one way anova). Parameter yang diukur meliputi post partus anoestrus interval (PPAI), service per conception (S/C), waktu sapih, dan calving interval (CI), Conception Rate (CR), persentase kelahiran dan kematian pedet. Post Partus Anoestrus Interval dihitung sejak sapi induk melahirkan hingga teramati pertama kali terlihat tanda-tanda estrus. Service per conception dihitung jumlah perkawinan sapi induk hingga induk menjadi bunting; sedangkan CR dihitung jumlah sapi induk bunting pertama kali dikawinkan dibagi jumlah induk yang dikawinkan kali $100 \%$. Calving interval dilakukan jumlah hari sejak induk melahirkan sampai sapi induk beranak lagi. Lama sapih dihitung sejak pedet lahir sampai pedet disapih dan persentase kelahiran dihitung jumlah sapi induk dalam satu populasi.

Data dukung lain yang diamati adalah bobot badan (BB), Pertambahan Bobot Badan Harian (PBBH), Skor Kondisi Tubuh (SKT), dan ragam pemberian pakan sapi. Semua prosedur yang dilakukan dalam penelitian ini telah ditinjau dan disetujui oleh Komite Etika Hewan Universitas Queensland sesuai dengan Kode Etik Australia untuk Perawatan dan Penggunaan Hewan untuk Tujuan Ilmiah.

\section{HASIL DAN PEMBAHASAN Performans Reproduksi Induk}

Selama penelitian berlangsung, beberapa parameter reproduksi induk yang diamati tertera pada Tabel 1 .

Tabel 1.Performans reproduksi pada sapi PO induk dengan waktu perkawinan berbeda

\begin{tabular}{lccccc}
\hline \multirow{2}{*}{ Parameter } & \multicolumn{4}{c}{ Waktu Perkawinan Sapi Induk (rataan \pm SD) } & \multirow{2}{*}{ Nilai P } \\
\cline { 2 - 5 } & I & II & III & IV & \\
\hline Post partus Anoestrus in- & $44,7 \pm 6,2^{\mathrm{a}}$ & $71,5 \pm 15,9^{\mathrm{b}}$ & $92,1 \pm 23,0^{\mathrm{c}}$ & $132,8 \pm 48,1^{\mathrm{d}}$ & 0,00 \\
terval (hari) & & & & & \\
Servive per Conception & $1,4 \pm 0,6$ & $1,5 \pm 0,7$ & $1,2 \pm 0,5$ & $1,4 \pm 0,7$ & 0,24 \\
Conception Rate $(\%)$ & 66,67 & 64,91 & 79,45 & 71,19 & - \\
Calving Interval (hari) & $417,9 \pm 99,6^{\mathrm{p}}$ & $424,3 \pm 67,0^{\mathrm{p}}$ & $427,4 \pm 90,0^{\mathrm{p}}$ & $499,0 \pm 123,4^{\mathrm{q}}$ & 0,03 \\
Calving rate (\%) & 94,44 & 98,25 & 97,26 & 95,16 & - \\
\hline
\end{tabular}

Keterangan: Superskrip berbeda ${ }^{\text {abcd }}$ pada baris yang sama menunjukan beda nyata $(\mathrm{P}<0,01)$

Superskrip berbeda ${ }^{\text {pqrs }}$ pada baris yang sama menunjukan beda nyata $(\mathrm{P}<0,05)$ 
Post partus Anoestrus Interval pada sapi induk Peranakan Ongle (PO) di kondisi peternakan rakyat menunjukkan perbedaan sangat nyata $(\mathrm{P}<0,01)$ antara kelompok waktu perkawinan; dengan nilai PPAI pada kelompok I, II, III, dan IV masing-masing adalah $44,7 \pm 6,2 ; 71,5 \pm 15,9 ; 92,1 \pm 23,0$ dan $132,8 \pm 48,1$ hari (Tabel 1). Waktu perkawinan yang melebihi 120 hari pasca beranak menunjukan nilai PPAI semakin besar sehingga berdampak terhadap panjangnya $\mathrm{CI}$. Ini berarti semakin lama APP dan waktu perkawinan serta dengan tingginya nilai S/C, maka jarak beranak semakin panjang (Riyanto, Lutoyo dan Barcelona, 2015); demikain pula pendapat Susilawati dan Affandhy (2004) menyatakan bahwa kegagalan kebuntingan dan berulangnya IB menyebabkan angka S/C yang tinggi sehingga memperpanjang masa kosong pada sapi induk pasca berdampak terhadap panjangnya CI. Walaupun nilai PPAI pada sapi induk PO di kondisi peternakan rakyat menunjukkan perbedaan sangat nyata $(\mathrm{P}<0,01)$ antara semua perlakuan, namun nilai $S / C$ dan $C R$ antara kelompok perlakuan tidak berbeda nyata. Hal ini sesuai penelitian sebelumnya oleh Udin (2005), bahwa jarak kawin pertama setelah kelahiran tidak berbeda nyata dan bervariasi terhadap $\mathrm{CR}$ dan $\mathrm{S} / \mathrm{C}$.

Calving interval pada kelompok perlakuan IV menunjukkan nilai tertinggi $499,0 \pm 123,4$ hari $(\mathrm{P}<0,05)$ dibandingkan dengan dengan kelompok I, II, III $(417,9 \pm 99,6$ hari; 424,3 $\pm 67,0$ hari; dan $427,4 \pm 90,0$ hari). Jarak beranak dipengaruhi beberapa faktor, diantaranya PPAI, Mating Post Partus (MPP), DO dan S/C serta waktu kering maupun lama laktasi (Al-Amin, Hartono, dan Suharyati, 2017). Hal ini sama dengan hasil survei kinerja reproduksi sapi potong di Kecamatan Mojogedang yang menunjukkan bahwa nilai Post Partum Estrus (PPE) dan Mating Post Partus (MPP) masih panjang dengan tingginya S/C serta panjangnya DO dan CI (Riyanto, Lutoyo, dan Barcelona, 2015).
Conception Rate tertinggi dicapai pada kelompok III $(79,45 \%)$ daripada CR I, II dan IV (66,67\%; 64,91\% dan 70,55\%), dengan persentase kelahiran (calving rate) pedet pada kelompok I, II, III dan IV adalah 94,44\%; 98,25\% dan 97,26\% dan $95,16 \%$ (Tabel 1). Angka kebuntingan rendah disebabkan oleh rendahnya SKT dan pakan induk. Penyapihan pedet yang terlambat juga menjadi faktor induk terlambat birahi setelah melahirkan. Keterlambatan estrus menyebabkan terlambatnya perkawinan dan kebuntingan, yang berdampak terhadap panjang CI induk. Hal ini terlihat pada perkawinan induk sapi yang dikawinakan lebih 120 hari menunjukkan CI-nya mencapai 499,0 $\pm 123,4$ hari (Tabel 1). Peternak mengawinkan induknya setelah beranak dalam jangka waktu yang lama sehingga masa kosongnya menjadi panjang. Tingginya kegagalan IB menyababkan $S / C$-nya menjadi tinggi (Susilawati dan Affandhy, 2004). Dilaporkan oleh Ihsan dan Wahyuningsih (2011) bahwa sapi Peranakan Limousin memiliki nilai CI lebih tinggi (451,3 $\pm 19,61$ hari) dibandingkan dengan CI sapi PO (430 $\pm 43,72$ hari). Fauziah, Busono dan Ciaptadi ( 2015), menyatakan bahwa sapi Peranakan Ongole dan Peranakan Limousin pada paritas 2 (dua) dan 3 (tiga) masing-masing menunjukkan nilai DO dan CI-nya sebesar 117,8 $\pm 16,5$ hari dan 397,6 \pm 16,6 hari. Demikian halnya pada Sapi PO Kebumen S/C mencapai $1,97 \pm 0,20$,dan CI-nya mencapai 14,17 $\pm 0,67$ bulan (Kusuma, Ngadiyono, dan Sumadi, 2017). Calving interval dipengaruhi oleh faktor manajemen peternak meliputi umur pertama kali dikawinkan, pemberian pakan dan kondisi tubuh, umur penyapihan pedet. Calving interval pada sapi Bali di Kab. Pringsewu bisa mencapai 416,69 $\pm 70,03$ hari (Suharyati dan Hartono, 2016).

Setiap bangsa individu sapi terjadinya ovulasi adalah berbeda dan beragam antara 10-11 jam setelah akhir estrus (Waluyo, 
2014). Ovulasi pertama bisa terjadi pada sapi induk pasca melahirkan pada hari ke 62 hari post partum dengan model penyusuan bebas/unrestricted suckling (Sinclair et al., 2002); ovulasi sapi induk pasca beranak bisa mencapai 70-90 hari post partum apabila SKT rendah sekali (Crowe, Diskin, and Williams, 2014). Waktu kawin yang kurang tepat antara waktu berakhirnya kapasitasi sperma hingga sperma masuk ke dalam ovarium tidak bersamaan dengan lepasnya indung telur (ovum) sehingga terjadi kegagalan pembuahan yang berakibat pada kegagalan kebuntingan. Namun dalam penelitian ini, CR semua perlakuan sudah cukup baik bila dibandingkan hasil penelitian terhadap performans reproduksi induk sapi di Kecamatan Tompaso Barat, diperoleh CR
$(55,56 \%)$, S/C $(1,44)$ dan CI-nya 359,6 (Kasehung et al., 2016). Faktor lain yang juga bisa mempengaruhi kebuntingan sapi adalah timbulnya lendir pada sapi betina yang sedang birahi seperti yang dilaporkan oleh Irfan, Wahjuningsih, dan Susilawati (2017) menyatakan bahwa karakteristik lendir servik sebelum IB memberikan pengaruh terhadap keberhasilan kebuntingan sapi komposit dengan nilai ratarata $\mathrm{CR}$ terbaik diperoleh pada kondisi lendir kental, yaitu CR $68,00 \%$ pada sapi induk dan CR 50,00\% pada sapi dara.

\section{Performans produksi sapi induk}

Terjadi penurunan nilai SKT dan BB induk pasca beranak pada semua kelompok waktu perkawinan (Tabel 2).

Tabel 2. Bobot badan, skor kondisi tubuh sapi PO induk dengan waktu perkawinan berbeda

\begin{tabular}{lccccc}
\hline \multirow{2}{*}{ Parameter } & \multicolumn{4}{c}{ Waktu Perkawinan Sapi Induk (Rataan \pm SD) } & P \\
\cline { 2 - 5 } & I & II & III & IV & \\
\hline BB awal (kg) & $321,8 \pm 46,2$ & $331,2 \pm 61,5$ & $318,0 \pm 57,4$ & $321,5 \pm 55,8$ & 0,652 \\
BB akhir (kg) & $296,1 \pm 47,6^{\text {a }}$ & $316,4 \pm 54,5^{\text {b }}$ & $291,2 \pm 48,8^{\text {a }}$ & $293,3 \pm 48,1^{\text {a }}$ & 0,040 \\
PBBH (g/ekor) & $-175,3 \pm 410,8$ & $-157,8 \pm 357,8$ & $-308,6 \pm 375,6$ & $-301,4 \pm 326,9$ & 0,178 \\
SKT 1 & $2,8 \pm 0,4$ & $2,8 \pm 0,3$ & $2.8 \pm 0,3$ & $2,7 \pm 0,3$ & 0,747 \\
SKT 2 & $2,7 \pm 0,3$ & $2,7 \pm 0,3$ & $2,6 \pm 0,3$ & $2,7 \pm 0,3$ & 0,653 \\
Pertambahan SKT (\%) & $-13,2 \pm 0,2$ & $-7,5 \pm 0,3$ & $-12,3 \pm 0,3$ & $-4,6 \pm 0,2$ & 0,318 \\
\hline
\end{tabular}

Keterangan: Superskrip berbedab ${ }^{\text {ab }}$ pada baris yang sama menunjukan perbedaaan secara signifikan $(\mathrm{P}<0,05)$.

Faktor yang mempengaruhi penurunan SKT dan BB induk adalah nilai gizi dan konsumsi pakan induk, terutama pada sapi induk dua bulan setelah dan sebelum beranak membutuhkan gizi yang cukup yang bisa mempengaruhi efisiensi reproduksi (Ratnawati et al., 2016; Affandhy et al., 2011). Semua kelompok perkawinan pemberian pakan sapi induknya didominasi oleh jerami padi yang nilai gizi pakannya rendah dan sedikit leguminosa atau dedak padi (Gambar 1). Kurangnya gizi pakan pada induk menjelang kelahiran hingga tiga bulan pasca beranak bisa mempengaruhi produksi susu induk yang dibutuhkan oleh pedet yang berdampak terhadap penurunan SKT. Pada semua kelompok perkawinan SKT-nya menunjuk- kan kurang dari tiga. Rendahnya SKT bisa mempengaruhi perkembangan follikel dan ovulasi sapi induk pasca beranak (Centurion-Castro et al., 2013). Ovulasi post partum pada sapi induk antara SKT sedang dan rendah masing-masing adalah 47,8 hari vs 57 hari setelah induk melahirkan (Sinclair et al., 2002); sehingga bisa mempengaruhi estrus dan waktu perkawinan pada sapi (Tabel 1). Untuk mengoptimalkan kembalinya ovulasi pada sapi adalah nutrisi pra-melahirkan yang tepat dan manajemen agar sapi melahirkan dalam kondisi tubuh optimal (SKT sebesar 2,753,0) dengan post-partum kehilangan kondisi tubuh dibatasi untuk SKT $<0,5$ (Crowe, Diskin, and Williams, 2014). 
Pertambahan Bobot Badan Harian selama pengamatan menunjukkan data yang sangat variatif sehingga nilai standar deviasi tinggi. Beberapa ternak menunjukkan nilai PPBH negatif, artinya bahwa terjadi penurunan BB badan selama laktasi. Pada keempat perlakuan tidak mmenunjukkan berbeda nyata akibat masa laktasi. Pada masa laktasi awal, kebutuhan akan energi sangat diperlukan selain untuk produksi air susu tetapi juga untuk mengembalikan fungsi normal reproduksi. Jika intake energi rendah atau tidak sesuai dengan kebutuhan maka akan terjadi keseimbangan energi negatif. Sunu, Hartuti, dan Hermanto (2013) menyatakan bahwa peningkatan dan penurunan konsumsi pakan biasanya diikuti dengan peningkatan dan penurunan bobot badan tiap minggunya, hal ini menunjukkan bahwa pertambahan berkorelasi positif dengan konsumsi nutrisi.

\section{Performans pedet}

Bobot lahir, BB sapih dan PBBH pedet hasil keturunan pada sapi PO induk pasca beranak tidak menunjukkan perbedaan pada semua kelompok perkawinan induk (Tabel 3).

Tabel 3. Bobot badan dan PBBH pedet dengan waktu perkawinan sapi induk berbeda

\begin{tabular}{lccccc}
\hline \multirow{2}{*}{ Parameter } & \multicolumn{4}{c}{ Waktu Perkawinan Sapi Induk (Rataan \pm SD) } & \multirow{2}{*}{ P } \\
\cline { 2 - 5 } & I & II & III & IV & \\
\hline BB lahir (kg) & $26,4 \pm 1,9$ & $26,4 \pm 2,1$ & $26,7 \pm 2,3$ & $26,4 \pm 2,0$ & 0,761 \\
BB sapih (kg) & $82,8 \pm 13,1$ & $84,9 \pm 15,2$ & $85,5 \pm 14,2$ & $85,6 \pm 14,5$ & 0,911 \\
PBBH (g/ekor/hari) & $508,5 \pm 108,7$ & $435,3 \pm 380,7$ & $400,0 \pm 335,2$ & $477,4 \pm 287,9$ & 0,508 \\
Waktu sapih (hari) & $104,5 \pm 15,3^{\mathrm{b}}$ & $92,8 \pm 22,5^{\mathrm{a}}$ & $103,3 \pm 21,7^{\mathrm{b}}$ & $105,3 \pm 23,7^{\mathrm{b}}$ & 0,01 \\
Calf mortality (\%) & 16,67 & 0,00 & 1,35 & 1,72 & - \\
\hline
\end{tabular}

Keterangan: Waktu perkawinan I ( $<60$ hari), II (60-<90 hari), III (90-<120 hari dan IV ( $>120$ hari)

Superskrip berbeda ${ }^{\text {ab }}$ pada baris yang sama menunjukan perbedaaan secara signifikan $(\mathrm{P}<0,05)$.

Tingkat mortalitas pedet pada kelompok I mencapai $16,67 \%$, lebih tinggi daripada kelompok lainnya. Tingginya kematian pedet pada kelompok perkawinan induk, akibat pemisahan induk-pedet secara langsung atau pedet tidak mau menyusu ke induknya karena pakan yang diberikan masih belum cukup. Produksi susu induk berkurang dan pedet tidak mendapatkan nutrisi yang cukup sehingga berdampak pada kematian pedet. Baco et al. (2014) melaporkan bahwa secara umum tingkat kematian pedet pra-sapih cukup tinggi terutama pada sapi Bali hingga mencapai 30-50 \% karena mothering ability dan produksi susu induk sapi Bali rendah. Perbaikan manajemen, diantaranya mempertahankan skor kondisi tubuh induk $>3$, dapat mendukung kehidupan pedet melalui produksi susu yang optimal (Ratnawati et al., 2016).
Perkawinan sapi induk pasca melahirkan kurang $<60$ hari pada penelitian ini menyebabkan kematian pedet yang tinggi $(16,67 \%)$. Penyebab kematian pedet yang tinggi akibat pakan induk rendah (Gambar 1). Pakan induk pasca melahirkan digunakan untuk menormalkan kondisi ovarium sapi pasca beranak; produkisi susu dan kembali siklus birahi. Umumnya sapi yang dikawinkan terlalu dini kemungkinan belum ovulasi walaupun sapi induknya tampak birahi. Ovulasi setiap bangsa sapi beragam antara 10-11 jam setelah akhir estrus (Waluyo, 2014). Ovulasi pertama bisa terjadi pada sapi induk pasca melahirkan pada hari ke 62 hari post partum dengan model penyusuan bebas (Sinclair et al., 2002); ovulasi sapi induk pasca beranak bisa mencapai 70-90 hari post partum apabila SKT rendah sekali (Crowe, Diskin, and Williams, 2014). Disarankan 
untuk menghindari kematian pedet untuk perkawinan sapi induk pasca beranak dianjurkan setelah 60 hari dan kondisi ovarium sudah normal.

\section{Ragam pakan sapi induk pasca beranak}

Selama kegiatan penelitian berlangsung, dilakukan pengamatan pemberian pakan sapi induk (Gambar1). Pemberian pakan sapi induk tertinggi dalam pakan basalnya adalah jerami padi, yaitu di atas $12 \mathrm{~kg} / \mathrm{ekor} / \mathrm{hari}$ yang dikuti dengan rumput lapangan, rumput gajah, daun gamal, tumpi jagung dan dedak padi (Gambar 1). Perbaikan pakan melalui pemberian pakan tambahan pada induk sapi PO pada dua bulan sebelum dan setelah melahirkan mem- berikan pengaruh yang lebih baik terhadap bobot lahir, $\mathrm{PBBH}$, dan estrus post partus (Gustiani, Rismayanti, dan Sukmaya, 2014).

Nutrisi pakan induk yang rendah berpengaruh terhadap gangguan reproduksi lainnya, yaitu gangguan ovulasi, transpor sperma, fertilisasi, pembelahan sel dan perkembangan embrio/fetus (Ratnawati dan Affandhy 2009). Anestrus pada sapi juga merupakan permasalahan yang multifaktorial tetapi kemunculannya menandakan nutrisi yang tidak memadai, stres lingkungan, patologi uterus dan manajemen yang tidak tepat (Kumar et al., 2014).

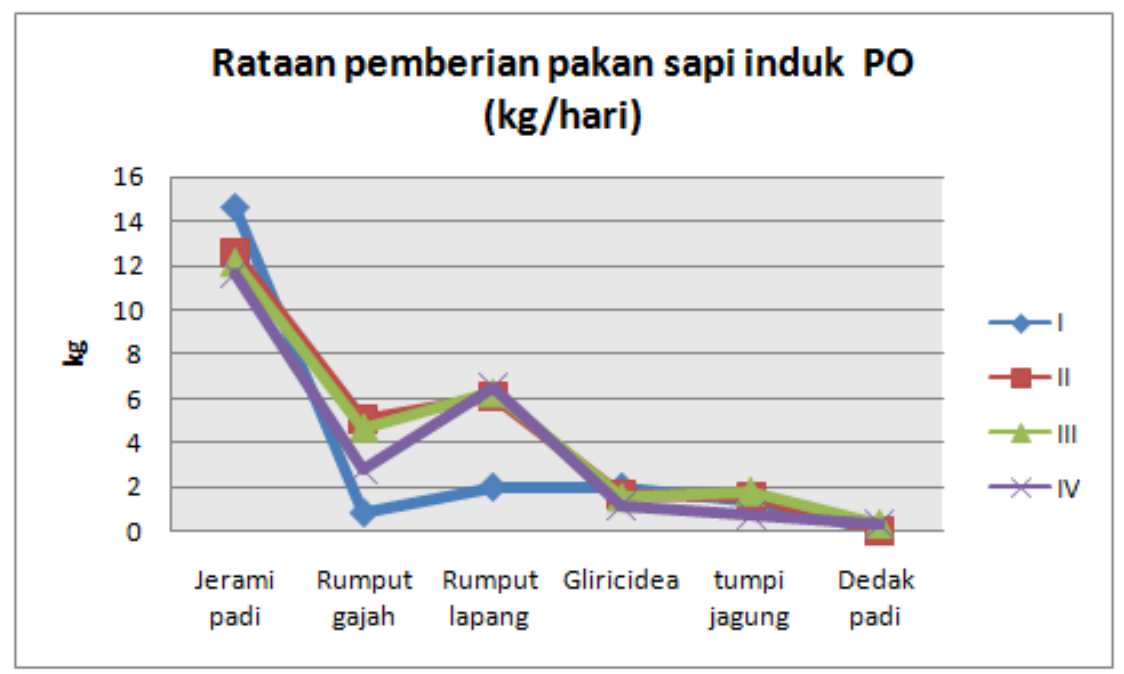

Gambar 1. Rata-rata pemberian pakan segar sapi induk PO selama penelitian

\section{KESIMPULAN DAN SARAN}

Waktu perkawinan pada sapi induk Peranakan Ongole yang paling efisien adalah $60-<90$ hari pasca beranak.

\section{UCAPAN TERIMA KASIH}

Terima kasih kami sampaikan kepada ACIAR untuk pendanaan ini penelitian dan semua tim proyek ACIAR LPS / 2008/038 (Dennis Poppi, Dianne Mayberry, dan Frans Cowley), serta petani desa, untuk semua tim kerja sama antara ACIAR, Australia dan Lolitsapi (Indonesia).

\section{DAFTAR PUSTAKA}

Affandhy, L., DM Dikman, T Wahyudi, DB Cahyono, DE Mayberry, G Fordyce, and DP Poppi. 2011. Reproductive performance of Ongole cows in Indonesian villages. Proceeding of Northern Australia Beef Research Update Conference. Holday Inn Esplanade, Darwin, 3-4 August, 2011. Published by the North Australia Beff Researh Council, PO BOX 846, (p 111). Park Ridge Q 4125.Australia. 
Affandhy,L., Aryogi, dan B. Tiesnamurti. 2014. Perkawinan Sapi Potong di Indonesia. IAARD Press.

Al-amin, A.F., M. Hartono dan Suharyati. 2017. Faktor-faktor yang memengaruhi calving interval sapi perah pada peternakan rakyat di beberapa Kabupaten/Kota Provinsi Lampung. JPPI, 1(1), 33-36.

https://jppi.fp.unila.ac.id

Astessiano, A.L., R. Pe' rez-Clariget, G. Quintans, P. Soca1, and M. Carriquiry1. 2011. Effects of a short-term increase in the nutritional plane before the mating period on metabolic and endocrine parameters, hepatic gene expression and reproduction in primiparous beef cows on grazing conditions. J. of Anim. Phy. and Anim. Nut., 96(3), 1-9. https://doi.org/10.1111/j.14390396.2011.01178.x

Baco, S. Basit, W., Rahmati, M., Dan Muhamad. H. 2014. Tingkat kematian dan pertumbuhan pedet sapi Bali melalui perbaikan manajemen dengan intervensi pakan konsentrat berbahan lokal. Pros. Seminar Nasional Optimalisasi Sumber daya Lokal pada Peternakan Lokal Berbasis Teknologi Peningkatan produktivitas Ternak Lokal. Fapet Univ Hasanudian, (PP10-19). Makasar.

Centurión-Castro, F., J. Orihuela-Porcayo. R. J. Aké-López, J. G. MagañaMonforte, R.C. Montes-Pérez, and J. C. Segura-Correa. 2013. Effect of body condition score on estrus and ovarian function characteristics of synchronized beef-caster 193 cows. Tropical and Subtropical Agroecosystems, $16.193-199$.

Crowe, M.A., M. G. Diskin, and E. J. Williams. 2014. Parturition to resumption of ovarian cyclicity: Comparative aspects of beef and dairy cows.
Animal, 8, 40-53. doi: 10.1017 / s1751731114000251

Fauziah, L. W., W. Busono dan G. Ciaptadi. 2015. Performnas reproduksi sapi peranakan ongole dan peranakan limosin pada parietas berbeda di Kecamatan Paciran Kabupaten Lamongan. J. Ternak Tropika, 16(2), 49-54.

https://doi.org/10.21776/ub.jtapro.20 $\underline{15.016 .02 .7}$

Gustiani, E., Y. Rismayanti dan Sukmaya. 2014. Kajian pemberian pakan tambahan terhadap produktivitas sapi PO di Kabupaten Subang. Agros., 16(2), 248-257.

Hastuti, D., S. Nurtini dan R Widiati. 2008. Kajian sosial ekonomi pelaksanan inseminasi buatan sapi potong di Kabupaten Kebumen. Mediagro, 4(2), 1-12.

Ihsan, M.N. dan S. Wahyuningsih. 2011. Penampilan reproduksi sapi potong di Kabupaten Bojonegoro. J. Ternak Tropika, 12(2), 76-80.

Irfan, S. Wahjuningsih, dan T. Susilawati. 2017. Pengaruh karakteristik lendir servik sebelum inseminasi buatan (IB) terhadap keberhasilan kebuntingan sapi komposit. J. Ternak Tropika, 18(1), 24-28.

Iskandar. 2011. Performan reproduksi sapi PO pada dataran rendah dan tinggi di Provinsi Jambi. Jurnal Ilmiah IlmuIlmu Peternakan, 14(1), 51-61. doi: https://doi.org/10.22437/jiiip.v0i0.58 $\underline{8}$

Kasehung, J., U. Paputungan, S. Adiani, dan J. Paath. 2016. Performans reproduksi induk sapi lokal Peranakan Ongole yang dikawinkan dengan teknik inseminasi Buatan Di Kecamatan Tompaso Barat Kabupaten 
Minahasa. Jurnal Zootek, 36(1), 167 $-173$.

Kumar PR, Singh SK, Kharche SD, Chethan Sharma G, Behera BK, Shukla SN, Kumar H, Agarwal SK. 2014. Anestrus in cattle and buffalo: Indian perspective. Adv. Anim. Vet. Sci., 2(3), 124-138.

http://dx.doi.org/10.14737/journal.aa $\mathrm{vs} / 2014 / 2.3 .124 .138$

Kusuma, S. B., N. Ngadiyono dan Sumadi. 2017. Estimasi dinamika populasi dan penampilan reproduksi sapi Peranakan Ongole di Kabupaten Kebumen Provinsi Jawa Tengah. Bull. Peternekan, 41(3), 230-242. https://doi.org/10.21059/buletinpeter nak.v41i3.13618

Ratnawati, D dan L. Affandhy. 2009. Implementasi sinkronisasi ovulasi menggunakan gonadotrophin releasing hormone $(\mathrm{GhRH})$ dan prostaglandin $\left(\mathrm{PGF}_{2 \alpha}\right)$ pada induk sapi Bali. Prosiding Seminar Nasional Teknologi Peternakan dan Veteriner. Pusat Penelitian dan Pengembangan Peternakan. (pp72-76), Bogor.

Ratnawati, D., Indrakusuma DA, Affandhy L, Cowley F, Mayberry D, Poppi D. 2016. Management strategies to improve reproductive performance of Brahman Cross cattle (Bos indicus) in East Java, Indonesia. JITV, 21(4), 231-237.

doi.10.14334/jitv.v21i4.1512

Riyanto, J., Lutojo dan D. M. Barcelona. 2015. Kinerja Reproduksi Induk Sapi Potong pada Usaha Peternakan Rakyat di Kecamatan Mojogedang. Sains Peternakan, 13(2), 73-79.

Sinclair, K.D., G. Molle, R. Revilla, J. F. Roche, G. Quintans, L. Marongiu, D. R. Mackey, , and M. G. Diskin. 2002. Ovulation of the first dominant follicle arising after day 21 postpartum in suckling beef cows. Anim. Sci., 75, 115-126. doi: https://doi.org/10.1017/S1357729800 $\underline{052899}$

Sudirman. 2016. Pengaruh Metode Perkawinan Terhadap Keberhasilan Kebuntingan Sapi Donggala Di Kabupaten Sigi. E-Jurnal Mitra Sains, 4(3), 22-27.

Suharyati, S. Dan M. Hartono. 2016. Pengaruh manajemen peternak terhadap efisiensi reproduksi sapi Bali di Kabupaten Pringsewu Provinsi lampung. Jurnal Penelitian Pertanian Terapan, 16(1), 61-67.

Sunu, K. P. W., Hartutik, dan Hermanto. 2013. Pengaruh penggunaan ajitein dalam pakan terhadap produksi dan kualitas susu sapi perah. JIIP, 23(2), 42-51.

Susilawati, T dan Affandhy, L. 2004. Tantangan dan peluang peningkatan produktivitas sapi potong melalui teknologi reproduksi. Lokakarya Sapi Potong. Puslitbangnak, (pp88-93) Bogor.

Udin, Z. 2005. Pengaruh kawin pertama pascapartum sapi potong terhadap angka kebuntingan di Kodya Padang. Bull. Peternakan, 29(4), 156-162. https://doi.org/10.21059/buletinpeter nak.v29i4.1183

Udin, Z., F. Rahim, Hendri dan Y. Yellita. 2016. Waktu dan kemerahan vulva saat inseminasi buatan merupakan faktor penentu angka kebuntingan sapi di Sumatera Barat. J. Vet., 17(4), 501-509.

doi:10.19087/jveteriner.2016.17.4.501

Waluyo, S.T. 2014. Reproduksi Aplikatif pada Sapi. Cetakan I. Penerbit P.T, Sewu (Srikandi Empat Widya). 